\title{
Places of Worship of the Common People in Ancient Egypt
}

Ahmed Ebied*

Faculty of Tourism and Hotels, Luxor University, Egypt

\section{ARTICLE INFO}

Keywords:

Common People

Worship

Social Status

New Kingdom

Ritual Worship.

\begin{abstract}
The ancient Egyptian considered the king the only priest in ancient Egypt. He is the link between the deities and human beings. Therefore, the priests were the substitutes that replace the king in performing the rituals. By consequence there is no place for the common people inside worship buildings. Therefore, their chapels are one of the most important manifestations of personal piousness in ancient Egypt. Although the common people did not enter the temples during the performance of the rituals, they were known for their extreme piety and endless religiosity. Based on the foregoing, the study explores the rituals of worship of the common people and the places of this worship away from the temple, which wasn't accessible area for them. The study attempts to answer the following questions: If the temple is the house of God and to which many people take refuge, then what is the case with the inhabitants of far villages and the workers of the desert? Where was the cult of the common people practiced? Did the Egyptian state at that time seek to establish private places or chapels for the common people? If they existed, did the ancient Egyptian satisfied with these places, or they had alternative places of worship for himself and his family? What were their characteristics? Was it restricted to certain people?
\end{abstract}

C2021 Faculty of Tourism and Hotels, Fayoum University All rights reserved

\section{Introduction}

The Egyptians believed in a pantheon of gods, which were involved in all aspects of nature and human society (Lichtheim, 1966). There are various words that describe god's intervention in human existence, such as: $r d i, w \underline{d}, s h r, s \check{s} m, \breve{s} 3$,

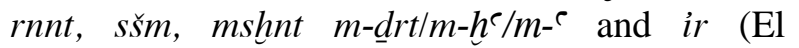
Ghazzawy, 2016) The ancient Egyptian considered the god as a companion and father, who would turn to him whenever he wanted (Assman, 1999). This was shown by some spells of Amun-Ra (Wilkinson, 2003; Andrews, 1994; Kamel, 2002).

\footnotetext{
*Contact Ahmed Ebied at: ahmed.ebied@fth.luxor.edu.eg
}

They believed that the gods exist all the time and look for them. He decides their destiny, ages, and the smallest details of their lives. To have the eternal life, they must proclaim their piety and prove that they fellow gods' orders. Thus, Egyptians seek to interact with the deities not only in their temples and shrines, but also in other places to have their satisfaction.

Because god is the sources of everything, he intervened in all people's hopes and prayers. They demonstrate their invocations in letters and biographies reflecting their conviction and of 
piousness. A text in the Instructions of Ptahhotep (Lichtheim, 1966):

$n$ p3 hryt n rmt hpr wdwt ntr pw hprwt

"People's schemes do not happen god's commands are what prevail".

Another text indicates the same concept in the Instructions of Amenemopet, New Kingdom, (Laisney, 2006):

iir.k $\operatorname{sm}^{\top} \mathrm{n} n \mathrm{p}$ itn iw.f $w b n$

dd imi n.i wdי snb di.f n.k hrw.k n $p 3$ ` $n h$

iw.k wd 3 .ti $r$ hry

"You shall pray to the Aten when he rises".

"Saying: "Grant me well-being and health".

"He will give you your needs for this life and you will be safe from fear".

\section{Literature review}

\subsection{Concept of the Common People}

Ancient Egypt had three main social classes: upper, middle, and lower. The upper class is limited to royal family, rich landowners, government officials, important priests. army officers, and doctors. The middle class was made up chiefly of merchants, manufacturers, and artisans. The lower class, the largest class in society, consisted of unskilled labourers. Most of them worked on farms. Prisoners that captured in wars became slaves and formed a separate class.

There is evidence that the conditions of the working class have gradually improved in the New Kingdom before the reign of king Ramesses III until the $1^{\text {st }}$ known labour strike in recorded history occurred during Year 29 of his reign as indicating in Harris papyrus (Wilkinson, 2013).

The word $n d s w$ used to refer to the common people (LA, II, 385). Also, it assigned to the persons $n \underline{d} s$ ( $n d s w)$, "small one," in texts from the Late Period (García, 1997), and to the $s$ njwt tn "man of this town" of the Middle Kingdom (Quirke, 1991). Gardiner indicates that the logical expansions of meaning are best shown by $3 \dot{i}$ "be great" and $n \underline{d} s$ "belittle"; both of which can sometimes relate not only to size, but also to age or rank. As a derivative noun (probably a participle), '3i may imply "be great in years" "be ancient", and hence "elder" or "potentate"; similarly, nd $\underline{d} s$ meaning "to be youthful", "lower person", and "commoner" as a derivative word (Fischer, 1973). A text indicates that (Urk, IV, 64: 10; Shmakov, 2012): jw hzwt.j hr wrw.s mrt.j hr nd $\underline{\underline{d} s w . s}$

"Grace for me is from its (i. e. the city's) great ones, love for me is from its little ones".
Many sources referred to common people, such as the Teaching of Khety which included many professions in ancient Egypt (Papyrus sallier II, col. IX, lines 2: 5; Helck, 1970). In his teaching:

"wn nfr n.k st $r$ n3 $n$ ỉwt dd.i $m$ hr.k" "mk iry hwrw.f iry"

"nn $\underline{d} d$ n.f 'hwty s"

"That is better life for you than these professions I show you"

"Protector of the worker, or his wretch the worker" "The field labourer of a man cannot say to him"

\subsection{Common People Chapels in Ancient Egypt}

The common people would supplicate to their deity during celebrations, feasts, and processions in which the image of the deity or his statue would go out, so they would approach him. But such activities were not enough to deepen religious thought and increase the personal piety of many, which made some individuals turn directly to the gods outside the temple walls (Shafer et al., 1991). It is worth noting that the term "personal piety" is used in ancient Egypt to describe some manifestations of the religious practices outside the common religious places. This manifestation was proved by the discovery of many votive paintings and some anthropoid busts dating to Ramesside Period at Deir El-Medina (Breasted, 1012). The same practices were described as the popular religion. Such practices didn't refer practiced only to ordinary people, but it was penetrated among all classes and groups, including peasants, craftsmen, servants, administrative middle class,' and higher officials, in addition to the established clergy (Janssen, 1975). Personal religious practices take place in different spaces: houses, tiny shrines, and cult places on the outskirts of the large official temples.

It is worth noting that in ancient Egypt there were many cult places which are restricted to common people (Clarysse, 2010; Wagner and Quaegebeur, 1973). These private cult's places could be divided into two:

\subsubsection{Inside the Divine Temple}

The ancient Egyptians regarded the temple to be the holiest place on earth which is known as pr ntr "the house of god" or hwt-ntr, means "mansion (or enclosure) of a god". The temple was a micro form of cosmos by having architectural elements that were ritually related to the earth, sky, and the primaeval mound of creation (Spencer, 1994; 
Snape, 1996). Hence, the king was the terrestrial image of the divine existence, the temple was exclusively open to him and the priest, except for a few areas inside or around the temple that was open to the public as: external walls, towers, gates, obelisks, temple roofs, roadways flanked by sphinxes, and open front courtyards (Johnson, 1994; Luiselli, 2011).

The inaccessibility of the temple was an anxious matter for the Egyptians to keep it pure and away of any violation. Therefore, the common people created parallel spaces and objects to practicing the rituals as indicating in religious literature (Guglielmi, 1994; Seidlmayer, 2006), paintings, deity statues, tiny chapels , and some small chapels created for the aim of giving physical spaces for common people to engage in personal religious practices such as what was discovered at Karnak's eastern temple (Luiselli, 2011), demonstrating the state's proactive role in promoting popular religious rituals in and around temple grounds.

The two eastern temples at Karnak might be the places reserved to common people for practicing their rites. One of these temples is thought to be the ideal place of king Thutmose III' for hearing Amun-Re at Karnak because this temple was isolated from the main Amun precinct by an enclosure wall and was located between the old town and the main temple. Scholars hypothesized that the Theban area's population had access to Thutmose III's temple and could pray to Amun-Re there.

After that, king Ramesses II constructed a second temple at the east side of Karnak temple complex to the east of that of Thutmose III. Because AmunRe, the god who hears prayer, is portrayed on the façade of Ramesses II's temple, scholars think that it as a location where the people's spiritual needs were addressed. According to scholars, the inhabitants of Thebes addressed their petitions to Ramesses II, who would then send them on to Amun-Re (Ausec, 2010).

The inscriptions from the temple of Thutmose III have no reference as "seat of hearing" but this designation was found in a secondary text discovered near the second pylon at Karnak. Unlike the inscriptions on the courtyard of Luxor temple, the text in his eastern temple do not describe it as a "place of hearing appeal of mankind to gods". Furthermore, there is no imagery connected with sites where Ramesses II reigned in the eastern temple. Additionally, iconographic scenes exist on votive material, and some votive stelae retain the title of "god who answers prayer" (Ausec, 2010). The only indication that this temple may have been a location for the Theban population to worship is a picture of Amun-Re, who hears prayer, welcoming his son Ramesses II on the outside of the north wall of Ramesses II's Eastern Temple's peristyle court (Ausec, 2010).

The common people went to the gates of the gods' temples to practice rites that were not structured by religious books or prescribed in any texts. They kept in mind the necessity to link with gods or the kings. It is possible that the eastern high gate at Medinet Habu was a place for the common people's praying. Ptah, who hears prayer, was portrayed on the southern tower of Ramesses III's eastern high gate at Medinet Habu; he has also been recognized by researchers as a hub for regular people's devotion. In this context, the temple has a duality of functions: there are official cults within the gods' temples and other parallel cults outside the temples that were introduced by the ordinary people (Bell, 1985). This area around the temple gates termed as $\breve{s} b 3 n d w 3$ rhyt (Wilkinson, 1994). It's worth mentioning that the ancient Egyptians

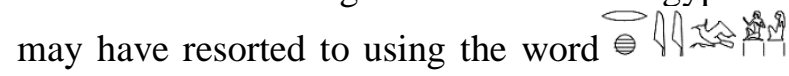
rhyt, or the raghet bird, to express indirectly the ordinary people (Nibbi., 1986; Hafez, 2016).

There is another evidence that rhyt refers to the common people. Egyptologists argue that the rekhyt were inscribed on the outer court's walls or columns as a indication that they had the right of access to some parts of the templs places (Wilkinson, 2000) as the forecourt. Beyond the purity warnings, Rekhyt are portrayed in more holy sections of the temple. Griffin has shown that the rekhyt rebus may also be found within the temple itself, where only priests are permitted; he believes they operate as part of the cosmos in this location and must be represented (Griffin, 2006). The rekhyt are performing a cosmic function in these situations, which does not imply that the public was permitted into the temple's sanctuary (Ausec, 2010).

There is an inscription on a block diorite statue in Musée de Louvre (A 134) for Habusenb hpw snb from $18^{\text {th }} \quad$ dynasty (fig. 1 , (https://collections.louvre.fr/en/ark:/53355/c10100 09461), have a recorded to the word ए sem-priest in the sanctuary of the rhyt Rekhyt 
(priest in the temple of wheat rekhit), which means the temple of the common people.

The divine processions were also a great opportunity for common people to keep themselves close to their deity (Sadek, 1987; Shafer, 2005), but the degrees of closeness and reverence differed from person to person. In the scenes of the Opet Feast at Luxor temple, there is one of the common people kneeling before the god Amun-Ra, while the other prostrated in complete reverence and awe and supplication to the god. (Lacau, 1977) (fig. 2).

\subsubsection{Inside the Mortuary Temples:}

The open court in the mortuary temples were places dedicated to the worship of the common people, specifically in front of what is known as the window of appearance (Kemp, 1976), which connects the temple with the palace attached to it, as was found in Medinet Habu (Helck, 1960; Trigger et al,1983).

\subsubsection{Outside the Temples}

The ancient Egyptians were keen to establish devotional shrines that has no connection to the world of temples. They are called the corners of worship, or what correspond today to the "chapels of worship "(زو ايا صغيرة للعبادة) (Hafez, 2020). There are many kinds of these chapels that divided into two types:

\section{Shrines constructed by common people}

Since Predynastic Period, home rituals have been one of the most fundamental representations of devotion and personal piety. There are numerous houses' walls that date back to Middle Kingdom, which refers to the home rituals activities (Gallorini, 1998) that grew in popularity throughout the New Kingdom period (Teeter, 1945).

During the early Middle Kingdom, the local religion of Aswan's deified governor Hekaib had a resurgence of popularity, and nomarch Sirenput I constructed a unique temple for him on Elephantine Island, complete with chapels arranged around a courtyard. locals and authorities dedicated their stelae and offering tables here in order to seek Hekaib's blessing on themselves and their undertakings. The shrine was visited by kings and nomarchs, but the inscriptions also feature calls to visits from the 'common folk' as well as the aristocracy; Hekaib even had an annual celebration, which coincided with the feast of Sokar (Habachi, 1956).
Two groups of documents attest to Imhotep's during the $30^{\text {th }}$ dynasty popularity among the common people: the numerous familiar stelae (JE 34205; Maspero, 1900) and the poorly made statues purchased by ordinary people to be used as ex-votos for Imhotep's cult, (Wildung, 1969) a text from the Ptolemaic Period gives the right for common people to have access to his temple. Also, Amenhotep son of Hapu became a homely god during the Graeco-Roman Period. There is a shrine for him at Deir el-Bahari (Bataille, 1949) where the common people pray (Malinine, 1962)

\section{Shrine constructed by country/State}

The state was keen to establish some places of worship in villages and simple streets throughout the country. It was subject to governmental supervision (Sadek, 1987; Hafez, 2020) and maybe it was for general worship without consecrating to specific deity. These sites particularly were under the king's patronage and therefore only partially used for "public" religion (Sadek, 1987).

This indicated the emergence of a group of booths since the New Kingdom, with a very simple layout, and a small statue or a painting of the idol is placed inside it, to which the public go to worship and make offerings. It was known as $\square$ क 40 hnw (Wb III, 288, 11-15). It was erected in the streets, villages, and cities. It was used by the common people in their worship. The most famous of these shrines were erected there to god Ptah, who was the most popular deity in Deir el-Medina (Stadelmann, 2001; Gahlin, 2001).

A number of these kinds of chapels have been discovered in the Deir el-Medina from the reign of king Amenhotep I, who built a "hnnu" for himself as a god (Hafez, 2020). Also, in the last line of king Arnenophis II's great stela, he speaks of ordering the construction of a "hnu" near the pyramids. This chapel and stela provide further evidence on the religious use of "hnu" (Sadek, 1987). Perhapse, there is a "hnu" of king Seti I (KRI, I, 243-281), a Khenu of king Ramesses II's near the temple of Hathor at the same place. Bruyere (1984) discusses the nature and function of this structure; it lacks most of the distinguishing elements of either a home or a tomb, making it neither civil (secular) nor funerary. Rather, it resembles other chapels at Deir el-Madina in the form of a succession of chambers leading to a sanctuary, so it is a religious construction. This structure is described as "his monument in the temple of his mother Hathor..., a 
hnw (chapel) of Ramesses II ..., an august site beside the temple of his mother Hathor" (KRI. II, 705: 4- 7)..

The evidence from Deir el-Madina denotes that there are two types of hnu: one dedicated to other gods or goddesses and the other for the people themselves. There is a hnu of god Amun-Re, god Ptah, god Qasarti (Sadek, 1987; Leibovitch 1948). Also, there is a chapel of god $\mathrm{hr} m 3 \mathrm{ht}$ in Dendera. The largest number of this type of shrines/ chapels was dedicated to goddess Isis and goddess Hathor (Sadek 1987). Small chapels were found near their places of worship, which are believed to have been built specifically for the common people, in Dendera, Edfu, and maybe in the temple of Isis in Philae (Preys, 2002).

Finally, depending on some remains of buildings from Pi-Ramesses, it's possible that there was a brick chapel (possibly more than one) with smaller images of the royal statues that served as the focal point of the cult (Habachi, 1954), similar to how the popular cult of the Great Sphinx at Giza was not practised directly in front of the Sphinx, but rather in brick buildings nearby (Sadek. 1987).

\section{Results and Discussion}

The concept of enhancing religious rituals among ordinary people had no relation with socioeconomic circumstances, but it was an unavoidable outcome of the religious environment in which the ancient Egyptian grew up.

The term "religion/ worship" is used to refer to a set of beliefs and behaviours held by humans in regard to a deity or deities. State Religion in ancient Egypt is a series of cults throughout the Delta and Nile valley. The goal of these rites was to obtain the gods' blessing and favour for all of Egypt, from the king down, their execution was the responsibility of specialists, and it was done almost entirely in private, away from the public, and it was a religion to which the public had almost no access. This was a religion for and on behalf of the people, but not one that was practiced by ordinary people. For the previous reasons, the common people in ancient Egypt, like other peoples, past and present, attempted to find means to communicate with deities in order to seek happiness and ward off affliction since the first historical times. This is something that spread widely in the era of the modern state and the late ages, and evidence for this is the remains of some shrines and votive paintings found in many holy places.
It is significant to note that many people have different perspectives: fear is to blame, the social issues that befell individuals in society as a result of events that occurred before the Amarna period, compelling some to undertake acts of worship, led others to establish the concept of individual or personal worship, also, desire to come together and become closer to God via the King's intercession, and as a result of Egyptian beliefs and practices, individuals have an innate sense of piety.

According to some spells of god Amun-Ra, there is an opinion that he appears in different forms because the common people do not see the great god except during the processions, so it was better for Amun to appear in the closest image to the poor people and listens to their supplications.

There is interaction and overlap between the 'State' and 'Popular' religion of the common people. This is to be anticipated, given that they are not two separate faiths, but two different manifestations of the same core religion (or collection of religions) spread over the same nation and society.

Both types of religion worship the same gods, popular religion has a tendency to adapt to formal religion's procedures and forms (in regular worship), and finally, on days of festival processions, when ordinary people may meet or follow the processions, or engage in a theatrical role, popular participation in official religion was limited, as found in several Abydos stelae (North, Kom es-Sultan), particularly the stelae Cairo Mus. Nos.20538, 20539 (Lange,1902), which belong to officials of Senusret I and Amenemhat III, and Berlin 1204 under Senusret III of the official Ikhernofret, make brief mention of the mysteries of Osiris that the common people participated in the great festivals of the dramatic death and resurrection of Osiris.

It is now evident after this enumeration of the common people chapels that the next studies must refer to the rituals that happened inside these chapels.

\section{Conclusion}

In conclusion, the common people were not allowed to practice religious rites inside temples, but they are naturally religious. Piety, and rituals of worship were not governed by social conditions because the ancient Egyptians found alternatives, and evidence for this is the appearance of some canvases made of linen which were decorated with 
carvings of the deceased and scenes of some deities.

The study revealed that workman's chapels in Deir el-Madina, Thebes, and Memphite may have been serviced as well by common Egyptians or by specific priests for these locations. The "hnu" was most likely little town-chapels (oratory) nestled among dwellings and other structures in the city's streets and maybe, both Egyptians and the foreigners were likely to attend these street chapels and after see these small buildings and many paintings he found, one can note that the common people and who belong to the poor class see the idea of worship as a way out of the difficult situation in which they live, promoting the idea that God is merciful and tolerant, and eternal life awaits them in which they enjoy all aspects of luxury and happiness.

\section{References}

Andrews, C. (1994). Amulets of Ancient Egypt, British Museum Press.

Assman, J. (1999). "Egyptian Religion", in: The Encyclopedia of Christianity, Fahlbusch, E., Lochman, J. M., Bromiley, G. W., Mbiti, J. S., Pelikan, J., Barrett, D. B., \& Vischer, L. (Eds.), (Vol. 2). Wm. B. Eerdmans Publishing.

Ausec, C. L. (2010). Gods Who Hear Prayers: Popular Piety or Kingship in Three Theban Monuments of New Kingdom Egypt. University Of California, Berkeley.

Baly, C. (1930). Notes on The Opening of The Mouth, JEA 16, 174.

Bataille, A. (1949) Aménôthès Fils de Hapou à Deir-elBahari, par André, Maître de Conférences à la Sorbonne, Bulletin de la Société Française D'égyptologie, 3, nos, 48.

Bell, L. (1985). Luxor Temple and the Cult of the Royal $\mathrm{Ka}, \mathrm{JNES}, 44$.

Breasted, J. H. (1912). Development of Religion and Thought in Ancient Egypt., London: Hodder and Stoughton, 1912.

Bruyère, B. (1984). Rapport sur Les Fouilles de Deir el Médineh (1934-1935), Imprimerie de L'Institut Français d'Archéologie Orientale, I.

Clarysse, W. (2010). Egyptian Temples and Priests: Graeco-Roman. A Companion to Ancient Egypt, 1, 274-290.

Dobrowolska, A., \& Dobrowolski, J. (2006). Heliopolis: Rebirth of the City of the Sun. American Univ in Cairo Press.

El Ghazzawy, A. (2016). The Will of God and Its Intervention in Human Life As Expressed In the Profane Literature from the Old Kingdom to the End of the New Kingdom.
Fischer, H.G. (1973). Further Evidence for the Logic of Ancient Egyptian: Diminishing Progression, JARCE, 10.

Gahlin, L. (2001). Egypt: Gods, Myths and Religion: a Fascinating Guide to the Alluring World of Ancient Egyptian Myths and Religion. Lorenz.

Gallorini, C. (1998). A reconstruction of Petrie's Excavation at the Middle Kingdom Settlement of Kahun. Lahun Studies, 42, 59.

García, M., Carlos, J., Études sur L'administration, Le Pouvoir et l'idéologie en Égypte, de l'Ancien au Moyen Empire. Aegyptiaca Leodiensia 4. Liège: Centre Informatique de Philosophie et Lettres, 1997.

Gardiner, A. (1932). Late Egyptian Miscellaies, Biblioteca Aegptiaca, Brxelles.

Gardiner, A. (1973). Egyptian Grammar, Being an Introduction to the Study of Hieroglyphs, $3^{\text {rd }}$ Edition, Revised, Oxford University Press, London.

Grajetzki, W. (2009). Court Officials of the Egyptian Middle Kingdom (Vol. 11). Bristol Classical Press.

Griffin, K. (2006). A Reinterpretation of the Use and Function of the Rekhyt Rebus in New Kingdom Temples, in Cannata M., (Ed.), Current Research in Egyptology.

Guglielmi, W. (1994). Die Funktion von Tempeleingang und Gegentempel als Gebetsort. Zur Deutung einiger Widder- und Gansstelen des Amun, in: R. Gundlach, M. Rochholz (Hrsg.), Ägyptische Tempel- Struktur, Funktion und Programm (Akten der Ägyptologischen Tempeltagungen in Gosen 1990 und in Mainz 1992), HÄB 37, Hildesheim.

Habachi, L. (1954). Khatâ'na-Qantîr: Importance, ASAE, 52.

Habachi, L. (1956). Hekaib the Deified Governor of Elephantine, Archaeology 9 (1).

Hafez, H. (2016). The Symbolism in Depicting the Conditions of the Parish (rhyt) during the Festival and Procession in Ancient Egypt, JGUAA 17, No. 17.

Hafez, H. (2020). The Diversity of Popular Cult Places and the Public Chapels hwt-rhyt since New Kingdom Period, JGUAA 1/21.

Hassan, H. (2011). Popular Gatherings in Ancient Egypt, Their Places and Functions, Unpublished PhD Thesis, Faculty of Archeology, Cairo University.

Helck, W. (1960). Materialien zur Wirtschaftsgeschichte des Neuen Reiches, III, Mainz.

Helck, W. ed. (1970). Die Lehre des $\underline{d} w 3-h t j j$, vol. 2, Otto Harrassowitz Verlag.

Hölscher, U. (1954). The Excavation of Medinet Habu/5 Post-Ramessid Remains. The Excavation of Medinet Habu.

https://collections.louvre.fr/en/ark:/53355/c1010009461 25-7-2021 
https://www.ucl.ac.uk/museumsstatic/digitalegypt/literature/satiretransl.html 25-72021

Janssen, J. (1975). Commodity prices from the ramessid period: An Economic Study of the Village of Necropolis Workmen at Thebes. Brill.

Johnson, W. R. (1990). Images of Amenhotep III in Thebes: Styles and Intentions. The Art of Amenhotep III: Art Historical Analysis, 26-46.

Johnson, W. R. (1994). Honorific Figures of Amenhotep III in the Luxor Temple Colonnade Hall. For his Ka: Essays Offered in Memory of Klaus Baer, 133-144.

Kamel, S. (2002). Unconventional Forms of Deities, Unpublished Ph.D. Thesis, Faculty of Archeology, Cairo University.

Kanawati, N. (1968) Work and Workers in the Old State in Pharaonic Egypt, Unpublished MA Thesis, Faculty of Arts, Alexandria University.

Kemp, B. J. (1976). The Window of Appearance at elAmarna, and the basic structure of this city, The Journal of Egyptian Archaeology, 62 (1), 81-99.

Kemp, B. J. (1995). How religious were the ancient Egyptians? Cambridge Archaeological Journal, 5 (1), 25-54.

Lacau, P., Chevrier, H., Bonhême, M. A., \& Gitton, M. (1977). Une Chapelle d'Hatshepsout à Karnak.

Laisney, V. P. M. (2007). L'enseignement d'Aménémopé (Vol. 19). Gregorian Biblical BookShop.

Lalouette, C. (1984). Textes Sacrés et Textes Profanes de l'ancienne Égypte.

Lange, H. O. (1902). Grab-und Denksteine des Mittleren Reichs im Museum von Kairo. Reichsdruckerei.

Leibovitch, J. (1948). Un Nouveau Dieu ÉgyptoCananéen. Imprimerie De l'Institut Francais D'archeologie Orientale.

Lichtheim, M. (1996). Didactic Literature, in: Loprieno, A. (ed.) Ancient Egyptian Literature: History and Forms, Leiden: E.J. Brill, 243-263.

Lichtheim, M. (2006). Ancient Egyptian Literature: A book of Readings, vol. I, The Old and Middle Kingdoms. Berkeley, CA; London: University of California Press.

Lichtheim, M. (2006). Ancient Egyptian Literature: A Book of Readings, vol. II: The New Kingdom. Berkeley, CA; London: University of California Press.

Lloyd, A. B. (1983). The Late Period, 664-323 BC. Ancient Egypt, A social History, ed. by Bruce G. Trigger et al., Cambridge, 279-348.

Luiselli, M. M. (2011). Die Suche nach Gottesnähe. Untersuchungen zur Persönlichen Frömmigkeit in Ägypten von der Ersten Zwischenzeit bis zum Ende des Neuen Reiches. Ägypten und Altes Testament, vol. 73. Wiesbaden: Harrassowitz Verlag.

Luiselli, M. M. (2014). Personal Piety in Ancient Egypt, Religion Compass, 8 (4), 105-116., Retrieved on 18-6-2021 from https://onlinelibrary.wiley.com/doi/epdf/10.1111/r ec3.12106

Malinine, M. (1962). Une Lettre Démotique à Aménothès, Fils de Hapou, $R d E 14$.

Maspero, J. (1900). Le Musee Egyptien I.

Newberry, E. I. (1900). Extracts from my Notebooks II, PSBA, 22, 59-66.

Nibbi, A. (1986). Lapwings and Libyans in Ancient Egypt, De Publications.

Nims, C. F. (1971). The eastern temple at Karnak. Aufsätze zum 70. Geburtstag von Herbert Ricke, Bf 12, 107-111.

Pestman, P. W. (1968). Burial and Inheritance in the Community of the Necropolis Workmen at Thebes (Pap. Bulaq X and O. Petrie 16), Journal of the Economic and Social History of the Orient/Journal de l'histoire economique et sociale de l'Orient, 137170.

Porter, B., \& Moss, R. L. (1974). Topographical Bibliography of Ancient Egyptian hieroglyphic texts, reliefs, and paintings/Bd. 3, Memphis 3 Abû Rawâsh to Abûșîr. Topographical Bibliography of Ancient Egyptian Hieroglyphic Texts, Reliefs, and Paintings.

Preys, R. (2002). Isis et Hathor Nbtyt Rhyt. Bulletin De l'Institut Français D'archéologie Orientale, 102.

Quike, S. (1991). Townsmen in the Middle Kingdom: On the term sn niwt tn in the Lahun Temple Accounts. Zeitschrift Für Ägyptische Sprache Und Altertumskunde, 118 (2), 141-149.

Ranke, H., \& Biedenkopf-Ziehner, A. (1935). Die Ägyptischen Personennamen (Vol. 3). Glückstadt: JJ Augustin.

Rudolf, J. (2002). Gegenkapellen in der Thebaïs, 3.

Sadek, A. I. (1987). Popular Religion in Egypt during the New Kingdom. Gerstenberg.

Schäfer, H. (1904). Die Mysterien des Osiris in Abydos unter König Sesostris III: nach dem Denkstein des Oberschatzmeisters I-Cher-Nofret im Berliner Museum, Untersuchungen zur Geschichte und Altertumskunde Ägyptens.

Schulman, A. R. (1984). The Iconographic Theme:" Opening of the Mouth" on Stelae. Journal of the American Research Center in Egypt, 21, 169-196.

Seidlmayer, S. J. (2006). Frohe- und Andere Botschaften, Kult und Kommunikation im Alten Ägypten, In: U. Peter and S. J. Seidlmayer (eds.), Mediengesellschaft Antike? Information und Kommunikation vom Alten Ägypten bis Byzanz, Berlin: Akademie Verlag, 2006.

Shafer, B. E., Baines, J., Lesko, L. H., \& Silverman, D. P. (1991). Religion in ancient Egypt: Gods, myths, and personal practice. Cornell Univ. Press.

Shafer, E. B. (2005). Temples, Priests, and Rituals, an Overview, in Temples of Ancient Egypt, ed. by Shafer, E. B., Cairo.

Shmakov, T. (2012). Critical analysis of JP Allen's the ancient Egyptian pyramid Texts. Omsk-Tricht. 
Snape, S. (1996). Egyptian Temples, Buckinghamshire, Shire Publications.

Spencer, P., \& Murray, M. (1984). The Egyptian Temple: A lexicographical Study. Routledge.

Stadelmann, R., (2001). Sphinx, In: The Oxford Encyclopedia of Ancient Egypt III, 307

Teeter, E. (2002). Piety at Medinet Habu. Oriental Institute News and Notes, 172, 1-6.

Wagner, G., \& Quaegebeur, J. (1973). Une Dédicace Grecque au dieu Égyptien Mestasytmis de la Part de Son Synode (Fayoum- Époque Romaine), BIFAO 73.

Wildung, D. (1969). Die Rolle ägyptischer Könige im Bewußtsein Ihrer Nachwelt. Teil. 1: Posthume

\section{Figures}

Figure 1

Diorite statue of Habusenb, $18^{\text {th }}$ dynasty, Reign of Queen Hatshepsut, Louvre Museum

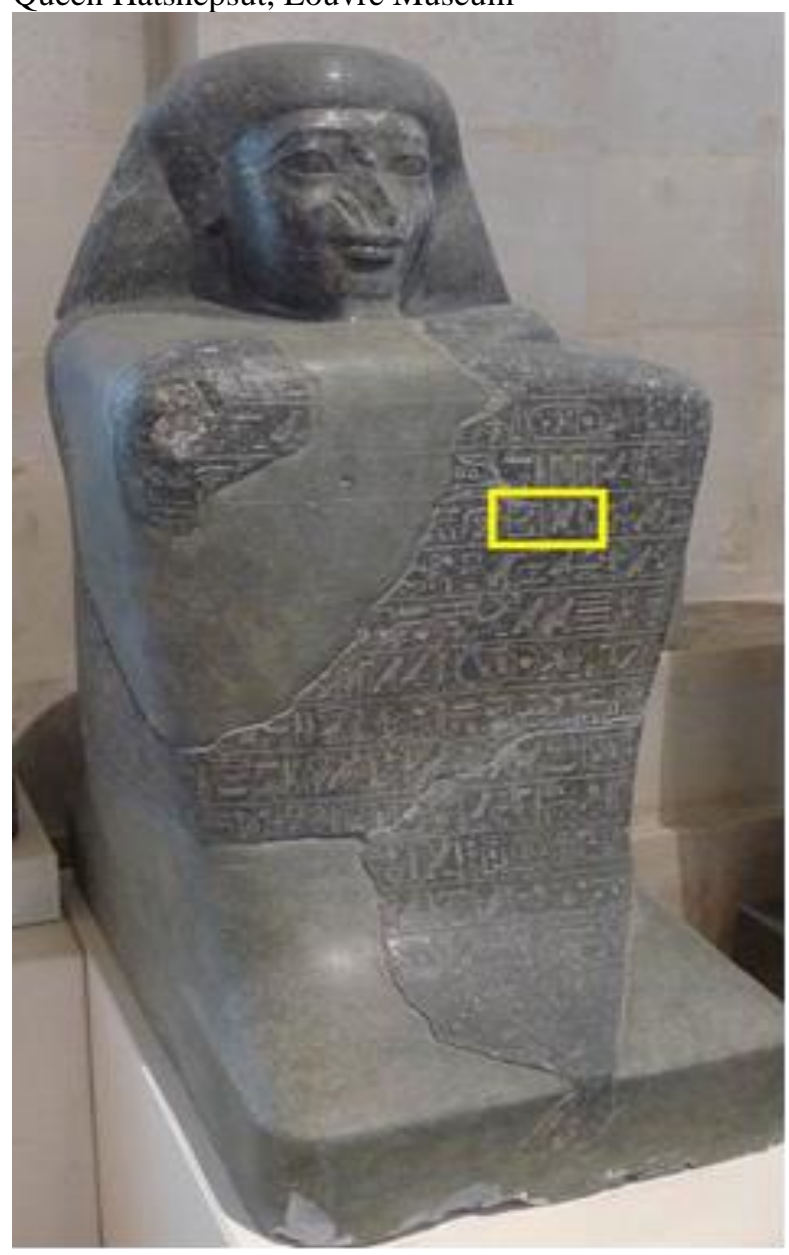

https://www.maat-ka-

ra.de/english/personen/hapuseneb/hapuseneb.htm retrieved $1 / 1 / 2021$
Quellen über die Könige der ersten 4 Dynastien. Münchner Ägyptologische Studien.

Wilkinson, R. H. (1994). Symbol \& Magic in Egyptian Art, Thames and Hudson.

Wilkinson, R. H. (2000). The Complete Temples of Ancient Egypt, Thames \& Hudson.

Wilkinson, R. H. (2003). The Complete Gods and Goddesses of Ancient Egypt, Thames \& Hudson.

Wilkinson, T. (2013). The Rise and Fall of Ancient Egypt, Random House Trade Paperbacks.
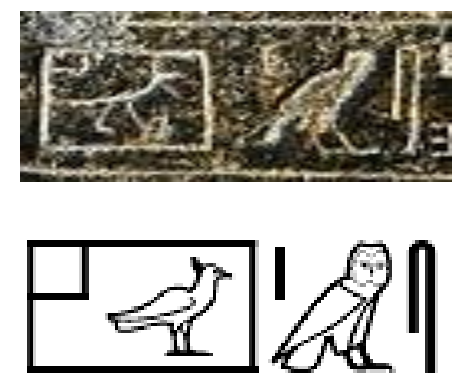
Figure 2

The Opet Feast processions, Luxor temple
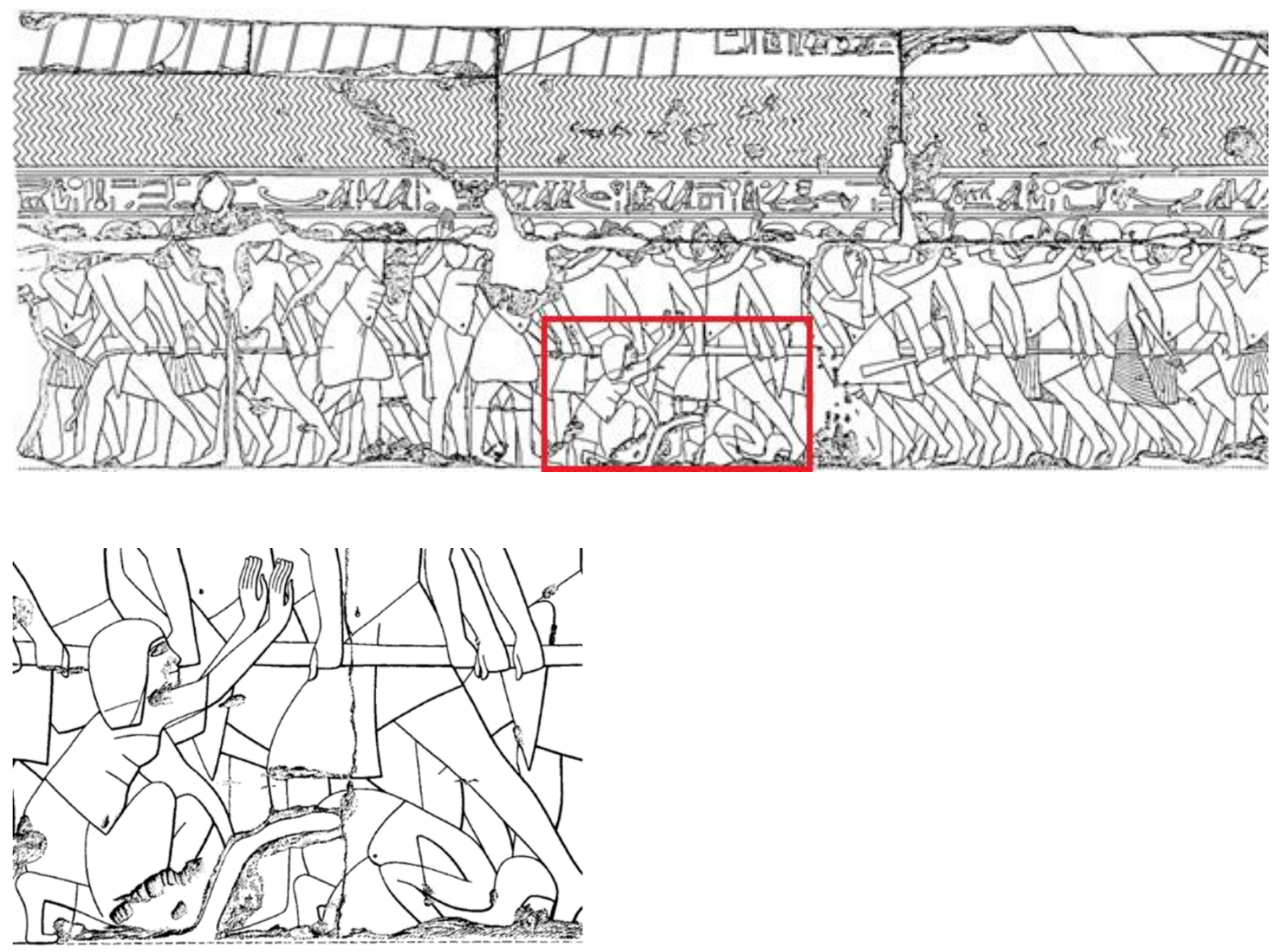

Lacau, P., Chevrier, H., Bonhême, M. A. and Gitton, M., Une Chapelle d'Hatshepsout à Karnak, 1977, p. 158 